\title{
Native and Non-Native EFL Teachers Dichotomy: Terminological, Competitiveness and Employment Discrimination
}

\author{
Mersad Dervić \\ International Burch University
}

Correspondence concerning this article should be addressed to Mersad Dervić, International Burch University, Francuske revolucije bb, 71210 Ilidža, Sarajevo, Bosnia and Herzegovina.

E-mail:mersad.dervic@ibu.edu.ba

\author{
Senad Bećirović \\ International Burch University
}

\begin{abstract}
Correspondence concerning this article should be addressed to Senad Bećirović, International Burch University, Francuske revolucije bb, 71210 Ilidža, Sarajevo, Bosnia and Herzegovina.

E-mail: senad.becirovic@ibu.edu.ba
\end{abstract}

\begin{abstract}
The application of 'native' and 'non-native' labels to EFL professionals has been influenced by the argument over their discriminatory nature. L1 proponents claim that natives are innate with linguistic competence while non-natives are referred to as second-best. A review of studies investigating the coherence of these terms supported the validity of this phenomenon. However, competing theories emphasise the importance and impact of discriminatory terminology not addressed by natives This paper looks at this debate in some detail and aims to balance the need for accurate descriptive labelling against the damaging effects of pejorative categories. It also discusses teaching and linguistic competence in light of both "native" and "non-native" categories. The discourse focuses on the advantages and disadvantages attributed to the native versus non-native EFL teacher and employment discrimination issues faced by non-native EFL teachers in institutions, job advertisements, and in the administration of institutions themselves today. It was concluded that a more refined approach to describing different types of EFL professionals is required, which does not negatively disadvantage either L1 or L2 teachers of English.
\end{abstract}

Keywords: Native, Non-Native, EFL, Teachers, Discrimination, Challenges

\section{Introduction}

The issue of employment discrimination affecting non-native teachers of the English language in the UK and worldwide is now pertinent and enduring (Clark \& Paran, 2007). The number of non-native English speakers, approx. 1.1 billion in the world, far outnumber native English speakers, approx. 400 million (Crystal, 2003). The main drives behind this increase in the numbers of English speakers, and in particular non-native English teachers, are assumed to be globalisation and the expansion of the EU's borders (Clark \& Paran, 2007). In their article Employability of Non-Native-Speaker Teachers of EFL, Clark \& Paran (2007) identified that the non-native status of teachers was a significantly influential criterion in the employability of non-native EFL teachers, as well as asserting that they are unlikely to ever be invited for an interview, even though these teachers are qualified, fluent in English, and experienced.

This article discusses teaching and linguistic competence for both "native" and "non-native" categories. Native teachers are often considered to be "ideal teachers" and "non-natives" their unequal counterparts (Shih \& Ying, 2017; Lurda, 2004). Thus, the paper will try to ascertain the background of such ideas, with the aim of clarifying the main issues that have been investigated in previous studies, i.e. why non-native teachers still face a range of 
negative experiences and attitudes in the current EFL workplace. This will test how to operationalise the terms native and non-native and identify the differences of opinion relating to the terms as well as examine if there is any consensus concerning the validity of the aforesaid labels.

Furthermore, the discussion focuses on competence issues related to non-native teachers in the EFL teaching profession: the advantages and disadvantages attributed to the native versus non-native EFL teacher and employment discrimination issues faced by non-native EFL teachers in institutions, job advertisements, and in the administration of institutions themselves today. It discusses the unfortunate persistence and impact of such discrimination upon the EFL teaching profession more generally, despite the increasing realisation that both L1 and L2 teachers have differing yet compatible skills to offer their learners. This issue of continued discrimination against non-native teachers is elaborated upon throughout the paper and concludes with recommendations for moving beyond such non-native discrimination within the EFL workplace.

\section{The Concept of a Native Speaker}

The first recorded description of what constitutes a native speaker is supplied by Davies (1991), who defined 'nativeness' as "the first language a human being learns to speak in his native language; he is a native speaker of this language" (p. ix). Moreover, the definition is in line with The Longman Dictionary of Applied Linguistics which defines a native speaker as "a person considered as a speaker of his or her native language" (Richards, Platt \& Weber, 1985, p. 188) and the Collins Co-build Advanced Learner's English Dictionary (2005) states that "your native language or tongue is the first language that you learned to speak when you were a child" (p. 950) ${ }^{1}$. Within these definitions, a native language can be described as the language that "a person acquires early in childhood because it is spoken in the family and/or it is the language of the country where he or she lives" (Richards, Platt \& Weber, 1985, p. 188)².

Davies (1991) also supports the previous meaning of 'native', and suggests that a person is a native speaker "of a language by virtue of place or country of birth" (Davies, 1991, p. ix), whereas Pannycook (1994) puts forward the idea that a native speaker is the "idealised person with a complete and possible innate competence in the language" (Pannycook, 1994, p. 175). Philipson (1992) takes a politically opposed position against such definitions which limits nativeness to a place of birth and assumes unrivalled competence of the native. Then, Philipson uses the English language as an example of the consequences of such definitions; he argues it leads to domination and imperialistic tendencies by the native over the non-native (Phillipson, 1992).

Some researchers provided a narrower Anglo-centric definition of the native speaker, defining them as someone who was born in an English-speaking country and has acquired the English language during their childhood in an English-speaking family or environment (Braine, 2010; Cook, 2005; Lee, 2005; Medgyes, 1994). This means that "the individual speaks English as his/her first language, has a native-like command of English and has the capacity to produce a fluent and spontaneous discourse" (Medgyes, 1994, p. 10). Hence, the native speaker is able to use the English language "creatively" and has a "reliable intuition" to distinguish "right from wrong forms" of the English language (Medgyes, 1994, p. 10). However, many scholars claim that the first language acquired by children is irrelevant in contrast to the mature first language, as children develop their system independent of the adult language system. Consequently, second language acquisition studies involve testing the cognitive ability of people who have successfully reached a usable level of the second language and not just how they have learnt it (Dervić \& Spahić, 2018; Cook, 2005; Lee, 2005 Medgyes, 1994; Davies, 1991).

A more simplistic definition of the terms 'native' and 'non-native' speakers describes the native speaker of a language as someone who speaks the language in question as to their first language and the non-native speaker as an individual who uses the language as a second or foreign tongue (Braine, 2010). Therefore, in order to provide a clear picture of a native speaker, Lee (2005) grouped six characteristics which evidently define a native speaker of a language. He suggests that a native speaker is an individual who:

- acquired the language in early childhood and maintains the use of the language,

- has an intuitive knowledge of the language,

- is able to produce fluent and spontaneous discourse,

\footnotetext{
${ }^{1}$ Collins COUBILD Advanced Learner`s English Dictionary. (2005). Great Britain, Beccles and London: William Clowes Ltd.

${ }^{2}$ Richards, J., Platt, J., \& Weber, H. (1985). Longman Dictionary of Applied Linguistics. England, UK: Longman.
} 
- is able to communicate within different social settings (communicatively competent),

- identifies with or is identified by a language community, and

- $\quad$ is freed from a foreign accent (Lee, 2005).

However, from the given definitions, it seems that it is impossible for any second language learner, regardless of their language competency, to become a native speaker; concluding anything learnt in later life cannot be qualified as a native language (Cook, 2005). Hence, the non-native speaker can acquire all previous characteristics save the "childhood acquisition" which indicates that the non-native speaker "does not acquire the target language in early childhood"; and even if that is the case, then they are "bilingual native speakers of both the L1 and the target language" (Davies, 2000, p. 5).

\section{Terminological Preference}

The native/non-native dichotomy is "one of the most complex and elusive areas in applied linguistics" (Medgyes, 1994, p. 9). Many scholars argue that such descriptions [native/non-native] are confrontational and offensive in relation to teachers of English language (Braine, 2010; Lazaraton, 2003; Jenkins, 2000; Suarez, 2000; Liu, 1999; Kachur \& Nelson, 1996; Rampton, 1990). Braine (2010) believes that the term "native" speaker certainly has positive connotations: it denotes a "birthright, fluency, cultural affinity, and sociolinguistic competence". On the other hand, the term non-native speaker carries the burden of the "minority, of marginalization and stigmatization, with resulting discrimination in terms of employability and professional advancement" (Braine, 2010, p. 9). Similarly, Kachur and Nelson (1996) feel that the terms "native and non-native" conceal attitudinal problems and that "...it is almost unavoidable that anyone [i.e. a potential learner] would select a second-best component” (Kachur \& Nelson, 1996, p. 79).

Recent research has suggested that using the label "non-native" speakers serves a political purpose (Liu, 1999, p. 97) or idea of separating people into different groups (Kamhi-Stain, 2004, p. 3). Furthermore, Amin (2004) states that the "native speaker is embedded in a myth" and that "myth-making" of the native speaker is related to discourses concerned with racism and colonialism which often reveal the negative impressions that have been formed about non-native English speakers (Amin, 2004, p. 62). The division native/non-native may generate discrimination which serves no purpose when related to assessing the level of proficiency acquired by the individual teacher (Amin, 2004, p. 74).

Attributes used to characterise the categories of 'native' and 'non-native' speakers can be challenging. On the basis of interviews conducted with teachers whose mother tongue was not English, Liu (1999) found that the majority did not have a problem with the distinction. However, a significant minority felt that it was a complex and even unusable distinction. Thus, Liu concluded a significant number of individuals chose to disregard this dichotomy of native/non-native and expressed concerns about affiliating themselves with either category. The reason why is most likely due to the idea that the labels native/non-native infer that native speakers are more efficient and capable of using and teaching the language than their counterparts.

Jenkins (2000) states that it is "entirely inappropriate and offensive" to use the label "non-native speakers" for individuals "who have learnt English as a second or foreign language" and thus are bilingual and also fully proficient speakers of English. This native/non-native dichotomy may cause "negative perceptions and selfperceptions" of non-native teachers. This can lead to discrimination against those labelled 'non-natives'. Teachers labelled as 'non-native' can be "refused places on EFL teacher training courses" or have their submissions turned down for publications in prestigious international journals. Hence, the "native" and "nonnative" labels provide a simplistic view of a complex situation that constitutes an "error in the making" (Jenkins, 2000, p. 9).

Suarez (2000) also comments that the use of native/non-native terminology is in many ways paradoxical: "native" is seen as a strongly positive term, and its negative opposite "non-native", as a result, becomes practically redundant (i.e. no one wishes to have the term perpetuation applied to them). This means that in practice the distinction only exists to generate the positive term "native" and this is what makes the use of such terminology paradoxical or logically problematic (Suarez, 2000, p. 1). An interesting footnote to this debate is provided 
by Murti (2002) who notes that in recent history, the term "native" was used within English with a negative connotation, carrying hidden meanings of "uncivilized" or "barbaric" (Murti, 2002, p. 27). It is now commonly used as a positive adjective to describe first language linguistic competence.

Furthermore, using more neutral terms to classify teachers would be less obnoxious and less disrespectful to both groups. Employing phrases such as "L1 English teachers" for those whose mother tongue is English, and "L2 English teachers" for those who have a mother tongue other than English, would be more appropriate and suitable (Suarez, 2000, p. 1; Rampton, 1990, p. 99). In addition, Suarez notes that the prefix "non" used with "native" carries negative connotations, which may help to generate or perpetuate prejudice towards non-native teachers as opposed to L1 English teachers (Suarez, 2000. p. 1).

Therefore, to help prevent negative implications, the following are the new terms proposed by Jenkins (2000) instead of the native/non-native division:

MES - “Monolingual English Speaker”, which stands for those L1 speakers who do not speak any other language fluently.

BES - "Bilingual English Speaker", which stands for both categories: L1 speakers who speak another language fluently, and for L2 speakers who speak English fluently.

NBES - "Non-Bilingual English Speaker", which stands for those "L2 speakers whose English may have progressed only to the level at which it serves their particular international communicative purpose" (Jenkins, 2000, p. 11).

The notion that observing native/non-native differences within the process of selecting or categorising teachers may be seen as a "taboo subject", especially within an increasingly politically correct arena, leading to the suppression of useful and important debates. In the arena of "global diversity", these categories become a "badly kept secret" (Suarez, 2000, p. 1); creating an awkward and conflicted situation within the broader professional agenda of ELT, which on the surface states that both parties are equal and can coexist successfully, but underneath cannot honour those principles. One could even go as far as to suggest that elaborating on the debate concerning the details of the native/non-native terminology is a form of procrastination, designed to defer engagement with the thorny and ethically doubtful justifications which underpin the distinctions in the first place.

However, Braine (1999) puts forward more appropriate labels intending to overcome the "identity crisis" that may exist among non-native professionals:
a. Second language speaking professionals,
b. English teachers speaking other languages,
c. Non-native speakers of English in TESOL/TEFL,
d. Non-native professionals in TESOL/TEFL,
e. Non-native teachers of English,
f. Non-native English-speaking professionals,
g. Second language teaching professionals,
h. Non-native English teachers (Braine, 1999, p. xvii)

Finally, a more sophisticated and respectable term that needs to be applied nowadays was suggested by Rampton a few decades ago: the "language expertise" of both "native" and "non-native" teachers. He believes that by using the term "language expertise", which is built into the structure of "language inherence" and "language affiliation", it will give a clearer picture of teachers both individually and overall. It will provide equal opportunities for all types of teachers and will put forward the similarities between nationality and language ability (Rampton, 1990, p. 100).

\section{Competence and Credibility of Native/Non-Native EFL Teachers}

According to Widdowson (1994), native speakers are the "authentic owners" of the English language and are therefore linguistically competent (Widdowson, 1994, p. 387). However, rather than just assuming their 'ownership' of English, in contrast, many language researches have written and discussed the issues relating to native and non-native teachers by considering the problem in a more inductive manner. They have looked at real students' and teachers' perceptions in relation to nativeness using interviews, surveys, and post-graduate 
studies, the results of which have also been debated in articles and journals (Kamhi-Stein, 2004; Douglas, 2003; Timmis, 2002; Suarez, 2000; Cook, 1999; Nayar, 1994; Medgyes, 1992; Davies, 1991; Golebiowska, 1985).

When it comes to using English internationally, Smith (1983) postulates that "native speakers need as much help as non-native speakers" and claims that there is "no room for linguistic chauvinism" (Smith, 1983, p. 7). He is suggesting that communicative competence in one linguistic environment, where a form of English is used as a major means of communication, does not necessarily privilege speakers from that environment as heavily as they might imagine when they move into another area where a different form of English is used. A good example of this might be the difficulty many English speakers from the southern part of England would have understanding Glaswegian, or a form of English used for everyday communication across the Indian subcontinent due to the variety of other languages used within the populous (Douglas, 2003). An English speaker from New York or the south of England may be surprised at how difficult they would find it to operate in these other Englishspeaking contexts. Douglas (2003) suggests that within the wider confines of the English language, the Standard Scottish English maintains a separate identity characterised by the inclusion of Scottish lexis, grammatical syntactic features, and pronunciation (Douglas, 2003). However, Suarez (2000) believes that native speakers are certainly considered more competent than non-native speakers. Thus, the non-native teachers perceive themselves as less competent, and so often feel embarrassed in the presence of native teachers, regardless of their qualifications. In addition, for reasons stated above, "foreign teachers" are less forthcoming when required to speak in public arenas (Suarez, 2000, p. 1). This inevitably means that their needs and views will be either underrepresented or misrepresented.

Timmis (2002), inspired by reading Carter and McCarthy's 1997 study of the nature of spoken English, notes that there are significant differences between the forms of English that are presented in ELT reference materials and the "corpus-attested" norms of everyday speech. Timmis (2002) observes the following:

The written-based grammars exclude features that widely occur in the conversation of native speakers of the English language, across speakers of different ages, sexes, dialect groups, and social classes, with a frequency that simply cannot be dismissed as an aberration (p. 240).

In addition, Timmis (2002) concludes that he is personally aware of the differences between the English language he teaches and the English language he speaks (Timmis, 2002).

This gap between classroom English and everyday language suggests that the language of EFL classes tends to be more formal and uniform than any real spoken English. This happens out of necessity because there are so many different types of English, dependent upon such factors as cultural region, generation, and class,(Dubravac, Brdarević-Čeljo, \& Bećirović, 2018). To be more practical , EFL materials and classes have to use a more standardised version of English. What Timmis (2002) appears to be suggesting is that second-language English speakers understand this formal classroom language well, and therefore, are just as capable of being EFL teachers as native speakers, once they have reached the required standard of English. It may even be the case that this understanding of the more formal language used in classes can give something of an advantage to L2 teachers of English.

Golebiowska (1985) does not agree with the fact that non-native teachers' command of English can be equal to that of native teachers. She suggests that non-native teachers of English are likely to be less competent and thus require language improvement classes at an appropriate level. Hence, the native speaker's command of English is not comparable to the foreigner; for Golebiowska, the native speaker will always have a better command of English (Golebiowska, 1985). Nayar (1994) supports Golebiowska's (1985) view, considering native teachers as speakers who have "linguistic identity". He states that native teachers possess skills of accurate and perfect competence, whereas non-native teachers are considered as "cognitively deficient, language-deprived, errorprone, socio-pragmatically ungraceful and unreliable speakers” (Nayar, 1994, p. 2).

Furthermore, Medgyes (1983) believes that acquiring natives' competence in the language, "recourse to all the nuances of referential, stylistic, and textual appropriateness" is an unreachable goal for any non-native teacher. Moreover, he describes non-native teacher competence thusly:

His speech is often long-winded as the right phrase will continually elude him, thereby forcing him 
into hazy and lengthy definitions. He will invariably avoid the use of phrases about which he is not entirely sure, thus assuming a flat and inexpressive style, particularly when it comes to free oral communication (p. 6).

Consequently, Medgyes (1983) refers to Corder (1973) when he writes: "We do not expect or require foreigners to be able to select the stylistically appropriate language with the same skill and control as the native speaker does. The native speaker finds it "inappropriate" in certain situations for a foreigner to use the same style of language as he would do himself. We can take an example from the usage of "slang". It is not only that the appropriate use of "slang" requires great familiarity with, and sensitivity to, the social life of an individual, unlikely to be acquired by a foreigner, but also that the use of any slang features by a foreigner is inappropriate. A foreigner can only use slang appropriately when he is no longer regarded as a foreigner" (Medgyes, 1983, p. 6).

The English language runs along a spectrum starting from zero competence and running up to native competence (Medgyes, 1992). For Medgyes, non-native teaching is progressing along this continuum, utilizing learning strategies, such as a continuing professional development plan and/or their more general life experience. Hence, foreign teachers may use different techniques as they have "learnt-to-use/use-to-learn" English progressively. However, their progress is towards a 'glass ceiling' regarding promotion within their employment (Medgyes, 1992, p. 341).

However, for Medgyes (1992) a further problem facing non-native speakers and making it difficult for them to match native users is that the former are still, and most likely will always be, using a kind of "imitation English". Hence, foreign teachers can never appear quite as authentic or creative "as those whom they have learnt to copy" (Medgyes, 1992, p. 341). However, the author criticises previous research in this field for lacking comparable variables [i.e. age, sex, education, profession, etc.]. Thus, for Medgyes, many details on the significance of the native/non-native distinction remain questionable.

In addition, Medgyes remarks that the "liberal-minded researcher" has tended to ignore the most obvious and relevant criteria for competency: i.e. whether the teacher speaks English as a first, second, or foreign language (Medgyes, 1992, p. 340). However, a successful second language learner can gain a native competence for the language and thus choose a native speaker membership even if the foreigner is outside of his native environment (Davies, 1991, p. 165). In addition, Cook (1999) brings a more liberal perspective to the debate, stating that the teaching of English language should not be focused only on native speakers, as non-native speakers ought to be considered as "successful multi-competent speakers, not failed native speakers" (Cook, 1999, p. 185).

\section{Advantages and Disadvantages of Native/Non-Native EFL Teachers}

Shin's article 'Preparing non-native English-speaking ESL teachers' in Teacher Development, Volume 12, Issue 1 , mentions that the difference between the advantages and disadvantages of native and non-native teachers is a highly complex issue to define and the label of "native/non-native is too simplistic and fails to capture the rich complexities associated with being a user of a language" (Shin, 2008, p. 60). However, despite the many uncertainties surrounding the study of the native/non-native divide, a significantly visible advantage that non-native English language teachers possess is their awareness of the grammar which is built into their understanding of language due to their previous language learning experience (Shih \& Ying, 2017; Liu, 1999). However, Medgyes (1983) describes any situation in which "non-native" teachers' feel unsafe in using the language they teach as a contingency towards adopting a "pessimistic or an aggressive attitude". Medgyes characterises this "pessimistic type of teacher" as obsessed with grammar. He suggests that they show less competence in pronunciation and lexical aspects of teaching and often omit dealing with issues of linguistic appropriateness (Medgyes, 1983, p. 2). For Medgyes, "aggressive teachers" are focused on grammar because they feel more confident in that area; this is why they tend to claim that knowing the language can be reduced to the knowledge of its grammar (Medgyes, 1983, p. 3). "Aggressive teachers" will also tend to avoid using "alternative sources to teach pronunciation", such as tape recorders or radio. Medgyes suggests this is because avoiding using authentic pronunciation sources "....allows them conceal their foreign deficiencies such as their accent" (Medgyes, 1983, p. 3). These "aggressive teachers" focus on grammar specifically instead of vocabulary as the English language has over 400,000 words, which cannot be learned and mastered even by native teachers in 


\section{MERSAD DERVIĆ, SENAD BEĆIROVIĆ}

its entirety. Furthermore, he states that "non-native" teachers are students of English as much as the students they are teaching, and so being both teacher and student simultaneously may create a state of "schizophrenia" (Medgyes 1983, pp. 2-6). This crisis of identity could limit the ability to teach as it affects the non-native teachers' level of confidence in English.

However, teaching English is about "knowledge, technique, and practice, skills that must be learnt and persevered with to gain success" (Widdowson, 1994, p. 387). This means that all teachers [native and non-native] are "made rather than born" and that the language-learning process, structure, usage, and capacity to explain and analyse language have to be "learnt" (Philipson, 1992, p. 14). In fact, Lee (2000) takes it further and believes that motivation, drive, enthusiasm, knowledge, skills, training, teaching techniques, and personality are the factors that make somebody a good teacher (Lee, 2000).

Thus, non-native teachers should be favoured as teachers of English due to their accomplishment of the stated requirements above, i.e. learning the "complex process" of acquiring English as a foreign language, therefore gaining an accurate and deep understanding of the cultural requirements of their students. Hence, non-native teachers are aware of the differences between the "mother tongue" and "target language", student difficulties, and have a "first-hand" experience of "utilizing" a second or foreign language (Lee, 2000, p. 1). This means that non-native teachers represent examples of people who have become successful second language users. Therefore, the non-native teacher is "living proof" of someone who has been through the same route as the students and has acquired another language successfully. On the contrary, the native teacher can only appreciate their experiences and problems "second hand" (Cook, 2005, p. 57). Philipson (1992) adds that the unqualified and untrained native teacher may display "ignorance" within the structure of the mother tongue (Philipson, 1992, p. 14). Hence, Phillipson (1992) writes that a teacher "is not adequately qualified to teach language merely because it is his mother tongue" (p. 15).

Interestingly, Golebiowska (1985) does not feel that non-native teachers' experience learning English as a second language gives them a significant advantage as language teachers. For Golebiowska (1985), the superior English knowledge of the native speaker outweighs any skills that the non-native speaker might be understood to have from learning English as a second language. Golebiowska (1985) even goes as far as to note that many English teacher training courses provide native teachers with the experience of learning another foreign language (i.e. not English) so that they can acquire some of the awareness of what it means to learn another language. In contrast, Golebiowska (1985) does not feel that this supplies the native teachers with any very valuable skills. Therefore, she almost completely discounts the non-native skills that Philipson (1992) drew our attention to above.

However, we can view the non-native teacher from a more positive perspective and understand them as serving as a practically "imitable model" for the successful language learner (Medgyes, 1992, p. 346). Nonnative teachers are good role models for foreign students, presenting themselves as successful English speakers, and so demonstrating English as a second language as an achievable target (Lee, 2000; Davies, 1991). On the contrary, the native speaker teacher who does not know the students' first language is only a "model of something unfamiliar" which students can never achieve. Additionally, the non-native teacher can "speak from personal experience" about the challenges of how second language learning has influenced their life. Finally, the appreciation of other "cultures and their feeling for language" is an advantage that the monolingual native teacher will never acquire and may not appreciate (Cook, 2005, pp. 56-7).

Furthermore, Medgyes (1992) describes non-native teachers as able to teach students general learning strategies and anticipate common difficulties more efficiently. In the case of "teachers who share the mother tongue" of their learners, they are also able to assist students through the translation of lexis and explanation of complex language features in the shared first language. This positive view sees non-native teachers as being able to provide an empathetic approach to their learners' needs and problems. Accordingly, when compared to native teachers, the non-native teacher could be "equal in being successful and effective" (Medgyes, 1992, pp. 346-7).

The native teacher is an authentic transmitter of culture (Bećirović \& Podojak, 2018) and the dichotomy of the terms 'native' and 'non-native' is evidently problematic and challenging in second language acquisition and foreign language education (Cook, 2005; Lurda, 2004; Murti, 2002; Thomas, 1999; Medgyes, 1992). However, Murti (2002) challenges the idea that non-native speakers of English will never achieve the equivalent level of 
proficiency as native speakers of the English language. Murti comments that:

...the non-native instructor can teach people from other cultures how to use somebody else's linguistic code in somebody else's cultural context and can bring about social change. Such productive interaction between two cultural communities, mediated by the non-native teacher, sensitizes each of these communities to the other's potential, revealing the infinitely layered nature of diversity (p. 29).

Additionally, he feels that non-native teachers who have experienced serious cultural prejudices in other social situations can help learners view emotionally charged issues from a historical and cultural distance.

Moreover, non-native teachers as "cultural go-betweens" are mediating in the interests of social change by resisting and challenging assumptions and expectations and are aware of the contentious nature of the relationship between two or more cultures (Murti, 2002, p. 29). This distinction between language and culture enrich non-native teachers as they continue learning throughout their life experiences and challenges through their knowledge of where "two cultures and two languages converge and diverge" (Medgyes, 1983, p. 6).

Lurda (2004) moves even further away and states that non-native teachers have the quality of bilingualism. For Lurda, this is an inherent advantage. Non-native teachers have the potential for a wider knowledge linguistically, obtained by using a broader set of learning strategies. Additionally, non-native teachers are able to display expertise relevant for the process of becoming bilingual due to their ability of expressing themselves in different languages. Additionally, it is important to highlight that second language users have "different minds from monolinguals" (Cook, 2005, p. 53). Thus, L2 users have "different language abilities" and different ways of thinking from a monolingual native speaker. The L2 user may be able to function independently across the two languages with a 'mental' ability which the "monolingual native speaker cannot emulate" and compete with under any circumstances (Cook, 2005, p. 53).

In spite of the fact that most non-native teachers have sufficient proficiency to accomplish their duties, Lurda (2004) admits that the non-native teacher does not show as much understanding and awareness of linguistic flexibility as the native speaker does. They tend to adhere rather too rigidly the old, native-speaker dominated, linguistic frameworks: in other words, following British or American rules. Native speakers have the advantage of adapting more rapidly to new rules and language forms in their mother tongue. This is why they tend to be considered the "ideal teachers" (Lurda 2004, p. 319). This is in line with Widdowson (1994) claiming that the native teacher "acquires accuracy and unique English" which makes him/her the guardian of "proper English and pedagogy" (p. 387).

However, as the English language became more advanced and highly developed, Widdowson (1994) postulates that this new and evolving English language should no longer be just the concern of the native speaker. It is the language of technical, scientific, and business communication of a global world. Even so, he still feels that it is an honour and very satisfying to be classified as a native speaker of a worldwide language functioning as international means of communication (Widdowson, 1994).

Finally, Lurda (2004) notes that the role of the English teacher may be starting to change. English language teachers are no longer seen as "ambassadors" of English or British/American culture, but are now ascribed to the progress of the English language globally (Lurda, 2004, p. 319). They are now increasingly becoming identified as mediators between the students' source and the targetlanguage and culture (Rizvić \& Bećirović, 2017). Whilst seeing bilingual skills as a non-native advantage in this global world, Lurda does expresses concern that as the number of foreign teachers increases, this may, theoretically, hinder the quality of the English being taught. Thus, native teachers may find that they will be required to gain knowledge of the 'conversions' that take place between 'local' British or American English and the international language standards of a global English (Lurda, 2004). In this sense, native speakers will need to help maintain the quality of English used, but will increasingly need to act as mediators between local and international English. Thus, the dominance of British English will be lost. Hence, within the global English community, native speakers will increasingly be required to learn the conventions of English as an International Language (Lurda, 2004). 


\section{Employment Discrimination}

There are only a few studies (Shih \& Ying, 2017; Clark \& Paran, 2007; Pacek, 2005; Medgyes, 1994/2) that have been carried out in the field of discrimination against non-native English teachers both in the UK and internationally. The lack of research regarding discrimination in this field is in view of it possibly having "political and economic consequences, as well as raising questions about the academic integrity of its institutions [TEFL/ TESOL]" (Clark \& Paran, 2007, p. 417).

Philipson (1992) raises the "native speaker fallacy" issue by describing a native speaker as the "ideal teacher", which may exclude non-native teachers from EFL teaching positions (Philipson, 1992, p. 185).

According to Braine (1999), it seems that almost all native institutional administrators are trying to prevent the institutions they work for from hiring non-native EFL teachers. It appears to be that ELT is considered as the last field of the native speaker, which must be defended under any circumstances (Braine, 1999). Canagarajah (1999) shares the same view with Braine (1999) and believes that "the native speaker fallacy protects jobs for Centre teachers in their home institutions from the Periphery [non-native]; a protectionist move which also monopolises the ESL teaching jobs in the Periphery" (Canagarajah, 1999, p. 82). Canagarajah also claims that Periphery institutions advertisements state, "only native speakers needed", further perpetuating the "native speaker fallacy", and thus native speakers' dominance is also imposed upon in these Periphery societies (Canagarajah, 1999, p. 83). Looking at similar issues, Liu (1999) suggests that the maintenance of the dichotomy between native and non-native teachers influences the recruiting process. Consequently, non-native English teachers are again seen to be less desirable than their native counterparts (Liu, 1999).

Thomas (1999) gives an example from a TESOL Convention she attended where the subject of debate was the hiring of non-native teachers. She came to the conclusion that prejudiced views state that anyone "who is not an NS of English cannot speak the language"; therefore, non-native teachers cannot be hired only because "they do not fit in the profile of the native speaker" (Thomas, 1999, p. 7). The emphasis upon not hiring nonnative speakers was based on the notion that L2 students do not wish to be taught by non-native teachers. Thomas is suspicious of this reasoning, as she argues that an "inner circle" exists based on the fallacy of a kind of English: "the right kind", which she claims undermines the competencies and proficiency of non-native teachers (Thomas, 1999, p. 7).

Clark \& Paran (2007) state that non-native teachers may "face discrimination" when seeking employment in the UK as employers have a "negative view of a teacher's non-native status". They believed that qualified, experienced, and legally employable non-native teachers, with the right to work in the UK, may not even be asked to interview just from their non-native status. They found that $70 \%$ of UK institutions [private language schools and universities] consider 'native speaker status' to be one of the conditions for recruitment (Clark \& Paran, 2007, p. 430).

Braine (1999) argues that "a significant number of native speakers in ELT do not support the employment of NNESs to teach English in ESL contexts and no issue is more concerning than that of discrimination in employment" (Braine, 1999, p. xvi). Additionally, he argues that "only a few NNSs have succeeded in breaking the unwritten rule 'No non-native speakers need to apply', as many program administrators have openly stated a desire not to recruiteNNSs at professional conferences and job interviews" (Braine, 1999, p. xvi). Moreover, he states that the "...most common excuse for this discrimination is that ESL students prefer to be taught by native speakers" (Braine 1999: xvi). Pacek (2005) also points out that those students assume that when studying in an English-speaking country they will be taught the English language by native teachers (Pacek, 2005).

Thomas (1999) confirms that non-native teachers face discrimination in employment from their students as well. Thomas (1999) states that non-native teachers "often find themselves in situations where they have to establish their credibility as teachers of TEFL before they can proceed to be taken seriously as professionals" (Thomas, 1999, p. 5). Furthermore, she points out that her students were disappointed when they heard that she was going to teach them English, as she was non-native English language teacher (Thomas, 1999). Therefore, she concludes that "we usually learn to value what we see valued and undermine what we see undermined" (Thomas, 1999, p. 8). In addition, the employment issues for non-native teachers are only one of the numerous 
problems they face, as well as that 'their accents are misunderstood, their qualifications are questioned and that they are marginalized in the profession' (Braine, 1999, p. xiii).

Medgyes (1994/2001) in his book 'The non-native teacher' refers to the reported issue of employment discrimination in the English Language Teaching Journal, Illes (1991, p. 87). A non-native teacher applied for a teaching position in a language school in London. Even though he was a highly qualified and experienced teacher, his applications were consistently turned down, and he was not even shortlisted. One of the reasons for rejection was the following:

I am afraid we have to insist that all our teachers are native speakers of English. Our students do not travel half-way around the world only to be taught by a non-native speaker [however good that person’s English may be] (Medgyes, 2001, p. 432; Medgyes, 1994, p. 68).

A similar situation was encountered by Braine when he applied for a teaching position at the university where he was doing his MA degree. He stated that his request for that position was turned down instantly while "some native speaking classmates who had no teaching experience were employed" (Braine, 1999, p. 22).

In addition, Medgyes (1994) carried out a similar survey in London and Paris of a group of 'highly sophisticated teachers, teacher trainers, applied linguistics and publishers' (Medgyes, 1994, p. 67). Most of the respondents were native speakers of English from London. He was given 50 responses to questions relating to "what participants recruiting preferences would be towards native and non-native teachers if they were the principal of a commercial ELT school in Britain". He found that no one chose the first option, which was "to recruit only native teachers even without qualification", whilst two-thirds of respondents preferred to hire a native teacher or non-native teacher with qualifications rather than a native teacher without ELT qualification. Only one-third of the respondents claimed that the native or non-native issue would not be a selection criterion. However, he concludes that the fact that no one selected the first option was a reflection of people's public principles. The respondents did not want to be seen as discriminatory against non-native teachers, as this would be seen as ethically inappropriate at a distinguished professional gathering (Medgyes, 1994, pp. 67-8). He adds that this was not the real business hiring practices of ELT schools in London faced with short-term economic decisions to make (Medgyes, 1994). In other words, prejudice was much more likely to be risked when money was involved, and the activity took on a business setting rather than an academic one.

Canagarajah (1999) points out that more than 80\% of English language teachers internationally are non-native speakers of English (Canagarajah, 1999, p. 91). Since many of them are presently enrolled in MA or Ph.D. TEFL training programs, and they all have to pay institutions fees, Canagarajah (1999) raises a series of questions such as: "For what purpose are these foreign scholars being trained? Have these institutions considered carefully the employment prospects for the students they train as teachers?” (Canagarajah, 1999, p. 83).

In order to provide an answer to the previously mentioned questions, Canagarajah (1999) argues that the institutions are training the students without considering the reality of the life they face after completing their teaching course. This is because the "native speaker fallacy" dominates and still seriously affects their chances of gaining employment. Non-native teachers face a future full of uncertainty in which their professional qualification is rendered useless in many ways, ironically often by the same institutions that taught the student. As a result, these students are at a serious financial disadvantage, and professionally, they are discriminated against and disqualified before they even begin to work. Initially, the process is a money-making machine that entices students with the promise of a better future, and eventually pushes them aside upon completion of the course. This kind of preferential treatment at a professional level stems from the institution's inherent desire to monopolise the English language market for the benefit of native staff (Canagarajah, 1999, pp. 83-4).

Unfortunately, this discriminatory character of many institutes is further evidenced in the advertisements for vacant teaching positions that they post A study by Selvi (2010) analysing the content of advertisements by TEFL institutes on a popular recruitment website found that there is a surprisingly high degree of discriminatory language used in advertisements (Selvi, 2010). Selvi establishes that this discriminatory approach serves to perpetuate the notions of native speakerism, characterized by the belief that native-speaker teachers represent a "Western culture" from which spring the ideals both of the English language and of English language teaching methodology (Selvi, 2010, p. 172) and this is also critically discussed by Holliday in his 2006 article, "Native- 
speakerism" in ELT Journal 60/4 (Holliday, 2006, p. 385). An adherence to native-speakerism legitimises the inequality and discriminatory nature of the advertisements. It assumes that the non-native is unequal to the native and the native is the owner and rightful teacher of English (Widdowson, 1994). This is constructed for the preservation of a privileged in-group: the natives (Kramsch, 1997, p. 363). Selvi (2010) found that in 91.2\% of 439 job advertisements, nativeness was a criterion which discriminated against the non-native (Selvi, 2010). Additionally, many of the advertisements discriminated against other variants of English, favouring American English in particular. Furthermore, in terms of educational attainment, the study found a preference for qualifications from either American universities or Anglophone countries (Selvi, 2010). Selvi concludes that this is a multifaceted phenomenon that discriminates "on the basis of nativeness as well as the variety of English spoken, location of academic degrees attained, and location of residence or citizenship" (Selvi, 2010, p. 173). Selvi's findings further support the idea that the "native speaker fallacy" raised as an issue by Philipson (Philipson, 1992, p. 185) is still strongly influencing employment decisions within TEFL and that the negative ideas embodied in versions of native-speakerism have not yet been relegated to the past, although Holliday drew attention to the need to review these ideas in 2006 (Holliday, 2006, p. 385).

\section{Conclusion}

In conclusion, we can infer that the non-native speaker is able to achieve all the assumed inherent characteristics that native speakers possess, except for the attribute of acquiring the target language in early childhood. Therefore, it is at least theoretically possible that very competent non-native teachers can deal with English in every way a native speaker can, with the exception of not being able to claim English as their first language. This idea of being 'born into' English is often used as a justifying basis for privileging the native-speaking teacher above the non-native teacher, without any further specific grounds for the distinction between the two. As a result, a two-tier categorisation is produced, with 'native' being associated with 'best' and 'non-native' with 'second best'. Yet there are no firm objective grounds for this distinction. No one would wish to choose to be considered as 'second best' (Kachur \& Nelson, 1996, p. 79). Therefore, the terminology produced disadvantages for the L2 teacher from the outset.

In light of this problem, many scholars have suggested more simplified and rational terms to replace the use of the native/non-native terminology. Furthermore, it is beneficial for both categories to be regarded as having forms of English expertise. We should also acknowledge that the English language has come to represent economic progress and political neutrality for the generations following WWII; thus, there is now no room for linguistic chauvinism. Therefore, it would be better to understand that both types of teachers can be equally successful and useful in teaching the English language.

However, despite the effort of some individuals in trying to balance out the relationship between native and non-native teachers, it is possible to conclude that discrimination in the employment of non-native teachers is still significantly present within both the UK and the international EFL teaching community. It seems that the notions of the native speaker fallacy, ownership, and native speakerism have contributed to the propaganda aimed at preventing non-native teachers' equality with native teachers. Thus, despite the numerous advantages of non-native teachers, it seems that 'foreign teachers' are still considered far from the concept of 'ideal teachers' of English (i.e. native teacher).

Finally, it is difficult to make predictions for the development of non-native teachers' career trajectories in the UK. The challenges that non-native teachers currently face are difficult to overcome as so many complex sociolinguistic and cultural factors play an important role in defining the non-native teachers' ability to teach the language in general. However, this is certainly the right time, not only for the UK but for the whole world, to add 'linguistic discrimination' to the list of unacceptable discriminatory policies that need to be legislated against, particularly in relation to employment law. All bilingual speakers would agree with the fact that learning a language is not an easy process and that complete mastery of a second language is difficult to achieve. Competent non-native teachers have gone a long way down the road to mastering a very useful and valuable skill. Therefore, they should be recognised as skilled instructors with serious contributions to make to EFL teaching. 
It is time for the UK government to get involved and start defending non-native teachers against the intolerance and favouritism that they have encountered within British educational institutions, which can still be perpetuated though the attitudes of administrators and finds its worst expression in discriminatory job advertisements. The implementation of laws designed to act against 'linguistic origin discrimination' would hopefully bring nonnative teachers career status in the UK and across the globe to the realistic and rational stage where they have to be treated equally to their native colleagues.

\section{References}

Adams, E. (2001). A proposed causal model of vocational teacher stress. Journal of Vocational Education and Training, 53(2), 223-246. https://doi.org/10.1080/13636820100200153

Amin, N. (1997). Race and the identity of the non-native ESL teacher. TESOL Quarterly, 31(3), 580-583. https:// doi.org/10.2307/3587841

Amin, N. (2004). Nativism, the native speaker construct, and minority immigrant women teachers of English as a second language. In L. D. Kamhi-Stein (Eds.), Learning and teaching from experience: Perspectives on nonnative English-speaking professionals (pp. 61-80). Ann Arbor, MI: The University of Michigan Press. https:// doi.org/10.3998/mpub.9648

Anthias, P. (2002). Student migration from Bangladesh to the UK. In Refugee, and migratory movements research unit (pp. 1-51). Dhaka, Bangladesh: University of Dhaka.

Bećirović, S. (2017). The relationship between gender, motivation and achievement in learning English as a foreign language. European Journal Contemporary Education, 6(2), 210-219. https://doi.org/10.13187/ ejced.2017.2.210

Bećirović, S., \& Podojak, S. (2018). Intercultural development of Bosnian university students through foreign language learning. European Researcher, 9(2), 68-77. https://doi.org/10.13187/er.2018.2.68

Benke, E., \& Medgyes, P. (2005). Differences in teaching behaviour between native and non-native speaker teachers: As seen by the learners. In E. Lurda (Eds.), Non-native language teachers (pp. 195-215). Boston, MA: Springer. https://doi.org/10.1007/0-387-24565-0_11

Bernat, E. (2008). Towards a pedagogy of empowerment: The case of 'impostor syndrome' among pre-service non-native speaker teachers in TESOL. English Language Teacher Education and Development, 11, 1-8.

Black, T. R. (1999). Doing quantitative research in the social sciences: An integrated approach to research design, measurement, and statistics. Thousand Oaks, CA: SAGE Publications.

Braine, G. (Ed.). (1999). Non-native educators in English language teaching. Mahwah, New Jersey: Lawrence Erlbaum Associates.

Braine, G. (2010). Nonnative speaker English teacher, research, pedagogy, and professional growth. London, UK: Routledge Taylor \& Francis. https://doi.org/10.4324/9780203856710

Canagarajah, A. S. (1999). Interrogating the "Native Speaker Fallacy": Non-linguistic roots, non-pedagogical results. In G. Braine (Eds.), Non-native educators in English language teaching (pp. 77-92). Mahwah, NJ: Lawrence Erlbaum. https://doi.org/10.4324/9781315045368

Clark, E. \& Paran, A. (2007). The employability of non-native-speaker teachers of EFL: A UK survey. An International Journal of Education Technology and Applied Linguistics, 35(4), 407-430. https://doi.org/10.1016/j. system.2007.05.002

Clouet, R. (2006). Between one`s own culture and the target culture: the language teacher as an intercultural mediator. Porta Linguarum, 5, 53-62.

Cook, V. (1999). Going beyond the native speaker in language teaching. TESOL Quarterly, 33(2), 185-209. https:// doi.org/10.2307/3587717

Cook, V. (2005). Basing teaching on the L2 user. In E. Lurda (Eds.), Non-native language teachers, perceptions, challenges and contributions to the profession (pp. 47-60). New York, NY: Springer. https://doi.org/10.1007/0387-24565-0_1

Crystal, D. (2003). English as a global language (2nd ed.). Cambridge, UK: Cambridge University Press. https://doi. org/10.1017/CBO9780511486999

Davies, A. (1991). The native speaker in applied linguistics. Edinburgh, Scotland: Edinburgh University Press. https://doi.org/10.1017/S0272263100011761

Davies, A. (2000). What second language learners can tell us about the native speaker: Identifying and describing exceptions. In R.L. Cooper, E. Shohamy \& J. Walters (Eds.), New perspectives and issues in educational language 


\section{MERSAD DERVIĆ, SENAD BEĆIROVIĆ}

policy: A festschrift for Bernard Spolsky (pp. 91-112). Amsterdam, Netherlands: Benjamins. https://doi. org/10.1075/z.104.08dav

Dervić, M., \& Spahić, N. (2018). an evaluation of five key aspects of the language acquisition (LA) - A critical review of Krashen`s theory. Zbornik radova Islamskog pedagoškog fakulteta u Zenici, 16(16), 391-408.

Douglas, F.M. (2003). The Scottish corpus of texts and speech: Problems of corpus design. Literary and Linguistic Computing, 18(1), 23-37. https://doi.org/10.1093/1lc/18.1.23

Dubravac, V., Brdarević-Čeljo, A., \& Bećirović, S. (2018). The English of Bosnia and Herzegovina. World Englishes, 37, 635- 652. https://doi.org/10.1111/weng.12347

Dunnett, S., Dubin, F., \& Lezberg, A. (1986). English language teaching from an intercultural perspective. In J. Valdes (Eds.), Culture bound (pp. 148-161). Cambridge, UK: Cambridge University Press.

Golebiowska, A. (1985). Once a teacher, always a teacher. ELT Journal, 39(4), 274-278. https://doi.org/10.1093/ elt/39.4.274

Holliday, A. (2006). Key concepts in ELT: Native-speakerism. ELT Journal, 60(4), 385-387. https://doi.org/10.1093/ elt/ccl030

Horwitz, E. (1996). Even teachers get the blues: recognizing and alleviating language teachers' feelings of foreign language anxiety. Foreign Language Annals, 29(3), 365-372.https://doi.org/10.1111/j.1944-9720.1996. tb01248.x

Jenkins, J. (2000). The phonology of English as an international language. Oxford, UK: Oxford University Press.

Johnston, B. (1997). Do EFL Teachers Have Careers? TESOL, 31(4), 681-712. https://doi.org/10.2307/3587756

Kachru, B. B., \& Nelson, C. L. (1996). World Englishes. In S. L. McKay \& N. H. Hornberger (Eds.), Sociolinguistics and language teaching (pp. 71-102). Cambridge, UK: Cambridge University Press. https://doi.org/10.1017/ cbo9780511551185.006

Kamhi-Stein, L. D. (Ed.) (2004). Learning and teaching from experience: Perspectives on non-native English-speaking professionals. Ann Arbor, MI: The University of Michigan Press. https://doi.org/10.3998/mpub.9648

Kramsch, C. (1997). The privilege of the nonnative speaker. PMLA, 112(3), 359-69. Retrieved from https://www. jstor.org/stable/462945?seq=1

Lasagabaster, D., \& Sierra J. M. (2005). What do students think about the pros and cons of having a native speaker teacher? In E. Lurda (Ed.), Non-native language teachers, perceptions, challenges and contributions to the profession (pp. 217-241). New York, NY: Springer. https://doi.org/10.12691/education-5-12-2

Lazaraton, A. (2003). Incidental displays of cultural knowledge in the non-native-English-speaking teacher's classroom. TESOL Quarterly, 37(2), 213-245. https://doi.org/10.2307/3588503

Lee, I. (2000). Can a non-native English speaker be a good English teacher? TESOL Matters, 10(1), 1-2.

Lee, J. J. (2005). The native speaker: An achievable model? Asian EFL Journal, 7(2), 52-163.

Liu, J. (1999). From their own perspectives: The impact of non-native ESL professionals on their students. In G. Braine (Ed.), Non-native educators in English language teaching (pp. 159-176). Mahwah, NJ: Lawrence Erlbaum Associates Publishers. https://doi.org/10.4324/9781315045368

Liu, J. (1999). Non-native-English-speaking professionals in TESOL. TESOL Quarterly, 33(1), 85-102. https://doi. org/10.2307/3588192

Lurda, E. (2004). Non-native-speaker teachers and English as an International Language. International Journal of Applied Linguistics, 14(3), 314-323. https://doi.org/10.1111/j.1473-4192.2004.00068.x

Marshall, G. (1998). A dictionary of sociology ( $2^{\text {nd }}$ ed.). New York, NY: Oxford University Press.

Martin, C. M. H. (1976). The training situation of the non-native EFL teacher in London. ELT Journal, 29(30), 101107. https://doi.org/10.1093/elt/xxix.2.101

Medgyes, P. (1983). The Schizophrenic teacher. ELT Journal, 37(1), 2-6. https://doi.org/10.1093/elt/37.1.2

Medgyes, P. (1992). Native or non-native: Who is worth more? ELT Journal, 46(4), 340-349. https://doi. org/10.1093/elt/46.4.340

Medgyes, P. (1994). The non-native teacher. London, UK: Macmillan Publishers. https://doi.org/10.12691/ education-5-12-2

Medgyes, P. (2001). When the teacher is a non-native speaker. Teaching English as a second or foreign language, 3, 429-442.

Mousavi, S. E. (2007). Exploring 'teacher stress' in non-native and native teachers of EFL. ELTED, 10, 33-41.

Moussu L., \& Lurda E. (2008). Non-native English-speaking English language teachers: History and research. Language teaching, 41(3), 315-348. https://doi.org/10.1017/S0261444808005028

Munro, J. M. (2003). A primer on accent discrimination in the Canadian context. TESL Canada Journal, 20(2), 3851. https://doi.org/10.18806/tesl.v20i2.947

Murti, K. (2002). Whose identity? The nonnative teacher as cultural mediator in the language classroom. ADFL 
Bulletin, 34(1), 26-29. https://doi.org/10.1632/adfl.34.1.26

Nayar, P.B. (1994). Whose English is it? TESL-EJ, 1(1). Retrieved from http://www.tesl-ej.org/wordpress/issues/ volume1/ej01/ej01f1/

O’Sullivan, I. R. (2010). The native rules. Humanising Language Teaching, 12(2), 1-5.

Pacek, D. (2005). Personality not nationality: Foreign students` perceptions of a non-native speaker lecturer of English at a British university. In E. Lurda (Eds.), Non-native language teachers, perceptions, challenges and contributions to the profession (pp. 243-262). New York, NY: Springer. https://doi.org/10.1007/0-387-24565$0 \_13$

Pannycook, A. (1994). The cultural politics of English as an international language. London, UK: Longman. https:// doi.org/10.4324/9781315843605

Philipson, R. (1992). ELT: The native speaker`s burden? ELT Journal, 46(1), 12-18. https://doi.org/10.1093/ elt/46.1.12

Phillipson, R. (1992). Linguistic Imperialism. Oxford, UK: Oxford University Press. https://doi.org/10.1017/ s0047404500019102

Rampton, M. B. H. (1990). Displacing the 'native speaker': Expertise, affiliation, and inheritance. ELT Journal, 44(2), 97-101. https://doi.org/10.1093/elt/44.2.97

Rizvić, E., \& Bećirović, S. (2017). Willingness to communicate in English as a foreign language in BosnianHerzegovinian EFL Context. European Researcher, 8(3), 224-235. https://doi.org/10.13187/er.2017.3.224

Selvi, A. F. (2010). All teachers are equal, but some teachers are more equal than others: Trend analysis of job advertisements in English language teaching. WATESOL NNEST Caucus Annual Review, 1, 156-181.

Sharpling, G. P. (2002). Learning to teach English for academic purposes: Some current training and development issues. ELTED, 6, 82-94.

Shih Y. T., \& Ying L. C. (2017). EFL college students' perceptions toward native and non-native English speaking teachers. American Journal of Educational Research, 5(12), 1182-1190. https://doi.org/10.12691/ education-5-12-2.

Shin, S. J. (2008). Preparing non-native English-speaking ESL teachers. An international journal of teachers' professional development, 12(1), 57 - 65. https://doi.org/10.1080/13664530701827749

Smith, L. E. (1983). English as an international language: No room for linguistic chauvinism. In L. Smith (Eds.), Readings in English as an international language (pp. 7-11). Oxford, UK: Pergamon Press. https://doi. org/10.1515/jelf-2015-0002

Stoler, A.L. (1997). Racial histories and their regimes of truth. Political Power and Social Theory, 11, 183-206.

Suarez, J. (2000). 'Native' and 'non-native': Not only a question of terminology. Humanising Language Teaching. Retrieved from http://old.hltmag.co.uk/nov00/mart1.htm

Sung, C. C. M. (2010). Native or non-native? Exploring Hong Kong students' perspectives. In Lancaster University Postgraduate Conference in Linguistics \& Language Teaching (vol. 4, pp. 1-18). Lancaster, UK: Lancaster university.

Tajino, A., \& Tajino, Y. (2000). Native and non-native: What they can offer? Lessons from team teaching in Japan. ELT Journal, 54(1), 3-11. https://doi.org/10.1093/elt/54.1.3

Thomas, J. (1999). Voices from the periphery: Non-native teachers and issues of credibility. In G. Braine (Ed.), Nonnative educators in English language teaching (pp. 5-13). Mahwah, NJ: Lawrence Erlbaum Associates. https:// doi.org/10.4324/9781315045368

Timmis, I. (2002). Native-speaker norms and International English: A classroom view. ELT Journal, 56(3), 240249. https://doi.org/10.1093/elt/56.3.240

Ustunluoglu, E. (2007). University students' perceptions of native and non-native teachers, Teachers and teaching: Theory and practice, 13(1), 63 - 79. https://doi.org/10.1080/13540600601106096

Walelign, A. (1986). Non-native speakers need not apply. English Teaching Forum, 24(2), 40-41.

Widdowson, H. G. (1994). The ownership of English. TESOL Quarterly, 28(2), 377-389. https://doi. org/10.2307/3587438

Wong, C.Y. (2009). Are native speakers 'good' language instructors? A case study of untrained ESL tutors. Annual Review of Education, Communication, and Language Sciences, 6, 122-140. 